Dossiê: Conferência de Medellín: 50 anos - Artigo Original ๑요

\title{
Medellín: história, símbolo e atualidade
}

\author{
Medellín: history, symbol and actuality
}

Afonso Tadeu Murad*

\begin{abstract}
Resumo
O artigo apresenta uma visão panorâmica dos documentos da Conferência dos Bispos latinoamericanos, realizada em Medellín, no ano de 1968. Inicialmente, distingue o Medellín histórico do Medellín simbólico. A seguir, recorda como a Assembleia foi bem preparada e se realizou de forma participativa. Então, demonstra a relação de continuidade com o Vaticano II. De outro lado, Medellín não foi uma mera aplicação do Concílio, mas sim uma recepção criativa. No núcleo do artigo, demonstra-se como o método VER-JULGAR-AGIR foi utilizado nos vários documentos de Medellín, alocados em três eixos: promoção humana, evangelização e crescimento da fé, Igreja visível e suas estruturas. Por fim, ele se detém em dois documentos: Pobreza na Igreja e Liturgia. Encerra-se com algumas conclusões abertas, de caráter pastoral.
\end{abstract}

Palavras-chave: Medellín; Igreja na América Latina; pobreza na Igreja; liturgia encarnada.

\begin{abstract}
The article presents a panoramic view of the documents of the Conference of Latin American Bishops, held in Medellín, in the year 1968. Initially, it distinguishes the Medellín historical from the symbolic Medellín. He then recalls how the Assembly was well prepared and carried out in a participatory manner. Then, it demonstrates the relationship of continuity with Vatican II. On the other hand, Medellín was not a mere application of the Council, but a creative reception. At the core of the article, it is shown how the VER-JULGAR-AGIR method was used in the various documents of Medellín, in three axes: human promotion, evangelization and faith growth, visible Church and its structures. Finally, he dwells on two documents: Poverty in the Church and Liturgy. It closes with some open conclusions, of pastoral character.
\end{abstract}

Keywords: Medellín; Church in Latin America; poverty in the Church; incarnate liturgy.

Artigo recebido em 10 de julho de 2018 e aprovado em 28 de agosto de 2018

* Doutor em Teologia pela Pontifícia Universidade Gregoriana, de Roma. Professor de Teologia na Faculdade Jesuíta (FAJE) e no Instituto Santo Tomás de Aquino (ISTA), em Belo Horizonte. País de origem: Brasil. E-mail: amurad@marista.edu.br

Horizonte, Belo Horizonte, v. 16, n. 50, p. 600-631, maio/ago. 2018 - ISSN 2175-5841 


\section{Introdução}

A Segunda Conferência Geral do Episcopado latino-americano aconteceu na cidade colombiana de Medellín, província de Antioquia, distante a $419 \mathrm{Km}$ de Bogotá por via rodoviária e a $240 \mathrm{Km}$ por avião. Até hoje, a estrada faz um percurso sinuoso pelas montanhas, com muitas subidas e descidas, totalizando mais de 10 horas de viagem em ônibus.

Medellín se realizou entre os dias 26 de agosto e o6 de setembro de 1968. Segundo M. Godoy, faziam parte da assembleia 249 pessoas, de vários países do nosso continente latino-americano. Dentre eles: 86 bispos, 45 arcebispos, 6 cardeais, 70 presbíteros e religiosos, 6 religiosas, 19 leigos e 9 observadores de outras igrejas cristãs (GODOY, 2015, p.211). Além deles, peritos ou consultores de diversos níveis.

Por ocasião dos 50 anos de Medellín se publicaram diversos artigos em revistas especializadas, no Brasil e em outros países da América Latina. No nosso país se destacam duas obras de envergadura, com aportes de uma plêiade de teólogos/as e pastoralistas: 50 anos de Medellín. Revisitando os textos, retomando o caminho (GODOY; AQUINO JÚNIOR, 2017) e Medellín: Memória, profetismo e esperança na América Latina (SOUZA; SBARTELOTTI, 2018).

Por que a conferência de Medellín se tornou tão significativa, a ponto de despertar a memória de um fato acontecido há 50 anos, suscitar reflexões e releituras para hoje? Qual a atualidade deste documento?

\section{0 histórico e o simbólico de Medellín}

Em breve texto publicado na revista "Tempo e presença”, 20 anos após o evento, J. B. Libanio pontua que "há dois Medellíns". Segundo ele, o Medellín histórico, aquele com data e local conhecidos, produziu uma série de documentos orientadores para a Igreja Católica na América Latina. Esse carrega a marca das 
circunstâncias, os limites de seu momento histórico, e o sentido de sua novidade (LIBANIO, 1988, p.22). Já o Medellín simbólico provém do primeiro, alimenta-se dele, projeta-o para o imaginário social coletivo e alça voo.

Atendendo um pedido insistente de um pequeno grupo de bispos do nosso continente, o evento Medellín foi convocado pelo Papa Paulo VI em julho de 1967, visando atualizar o Concílio Vaticano II para o contexto latino-americano. Essa iniciativa original ganhou ainda maior relevo, dado que o episcopado da América Latina, à parte algumas exceções como o jovem bispo Helder Câmara, tinha-se revelado no Concílio como um grupo tradicional e conservador. Os bispos representavam o que o filósofo brasileiro H.C. de Lima VAZ denominou como uma "igreja reflexo", que reproduzia aquilo que emanava da Igreja romana (VAZ, 1968). Ora, acentua Libanio, “os bispos europeus, assessorados pelos grandes teólogos, que alicerçavam os documentos do concílio, se mostraram sensíveis aos problemas da modernidade” (LIBANIO, 1988, p.22). Já na América Latina predominava uma sociedade agrária, pré-moderna, com uma religiosidade devocional.

De forma surpreendente, a Conferência de Medellín “deu uma virada”. Não somente aplicou os princípios de renovação do Vaticano II, mas foi além. Tornouse uma referência para o mundo. De forma singular, lançou os alicerces para organizar uma "Igreja comunidade", avançar na pastoral, refletir sobre a fé e atuar na sociedade. A conferência colocou as bases seguras para a teologia da Libertação e a "Igreja dos pobres".

(Medellín) abriu-se no horizonte da do "desenvolvimento integral" (Paulo VI Populorum progressio) e encerrou-se na perspectiva da libertação. Iniciou-se com bispos inquietos pela problemática social (..) e saiu-se com a firme determinação de opção pela libertação dos pobres. (LIBANIO, 1988, p.22).

Acrescentamos à reflexão de Libanio uma terceira dimensão: a da práxis pastoral. Se as afirmações, as intuições e as práticas estão vivas e encontraram eco nas Conferências subsequentes de Puebla (1979) de Aparecida (2007), isto se deve a uma multidão de pessoas que efetivaram o texto e o espírito de Medellín: bispos, 
padres, religiosas e religiosos, leigos e leigas, agentes de pastoral e teólogos (as). Vale destacar a atuação de bispos que, desde o "pacto das catacumbas", renunciaram aos seus privilégios, optaram por uma vida próxima do seu rebanho e abriram o caminho de uma real renovação pastoral e protagonismo dos leigos, especialmente os pobres (Pobreza na Igreja 8).

Surgiram figuras de pastores que souberam, a partir da herança do Concílio e de Medellín, caminhar profeticamente com seu povo, de modo particular com os pequenos e pobres, de maneira corajosa, na defesa de seus direitos e na promoção de sua dignidade e libertação. (BEOZZO, 2018, p.17).

Quando comemoramos os 50 anos da Assembleia, as dimensões histórica, simbólica e práxica se fundem, de forma que devemos recordar o evento, atualizar os sentidos e abrir caminhos pastorais. Vejamos algumas características singulares que marcaram Medellín.

\section{Assembleia participativa e bem preparada}

Ao nos referirmos à Medellín, utilizamos o termo "Conferência", pois constitui um evento formal e oficial da Igreja Católica, convocado pelo Papa Paulo VI, do qual participaram delegados escolhidos pelas Conferências Episcopais dos diversos países de nosso continente. Além disso, havia um delegado Papal e um representante da Pontifícia Comissão para a América Latina (CAL), nomeados pelo Vaticano. O segundo presidiu a Conferência, juntamente com o brasileiro Dom Avelar B. Vilela, arcebispo de Teresina e presidente do CELAM (Conselho Episcopal Latino-americano). Todos os 16 documentos foram votados e aprovados pelos bispos e presbíteros delegados, e posteriormente aprovados pelas instâncias romanas.

Portanto, não se trata de uma reunião qualquer, e sim de um evento eclesial e eclesiástico, com a força de um documento do magistério da Igreja Católica na América Latina. Uma expressão legítima da colegialidade episcopal (JOSAPHAT, 2015, p.150-152), da região do planeta com a maior concentração de cristãos e de 
católicos. Essa conferência está inserida no Rol das Conferências Gerais do Episcopado Latino-americano, da qual fazem parte: (1) Rio de Janeiro - 1955; (2) Medellín - 1968; (3) Puebla - 1979; (4) Santo Domingo - 1992; e (5) Aparecida (2007).

Falamos em América Latina como uma delimitação geográfica e cultural, do México à Argentina, de língua espanhola e portuguesa, de nações e povos que lutam para superar as consequências da colonização ibérica e fortalecer sua identidade comum. Nos últimos anos, vários organismos, como a CLAR (Conferência Latino-americana dos Religiosos/as da América Latina), agregaram à América Latina a expressão "e do Caribe”. Tal opção se justifica, pois essa região, constituída, sobretudo por países-ilhas na América Central, apresenta características linguísticas e culturais próprias, além de ter sofrido a ação de colonizadores diferentes, como franceses, ingleses e holandeses.

Dizemos também que em Medellín aconteceu verdadeiramente uma assembleia, dado o seu inegável caráter participativo. Essa foi preparada de forma aberta e cooperativa, sem deixar de ser sujeita às pressões de grupos. A preparação imediata se realizou em curto espaço de tempo. Mas foi efetiva. No início de 1968 , uma comissão de bispos e peritos elaborou o texto base, reformulado em junho do mesmo ano e apresentado aos bispos. Antes disso, realizaram-se diversos encontros sob a coordenação do CELAM (Conferência Episcopal Latinoamericana): sobre Educação, Catequese, Pastoral e missão, além de Assembleias de bispos sobre desenvolvimento, integração latino-americana e pastoral social (SOUZA, 2018, p. 35).

Dom Cândido Padim, então bispo de Baurú, recorda o $1^{0}$ Encontro sobre Pastoral de Conjunto, em 1966. Cita também o Seminário sobre Educação, um mês antes de Medellín, que contou com a participação de Paulo Freire, e assumiu o conceito de "Educação Libertadora” (PADIM, 2010, p. 228, 230). 
Todos os participantes, independentemente de seu "estado de vida" (leigo/a, presbítero ou consagrado/a), gênero ou confessionalidade, tiveram voz ativa nas comissões onde interviram. Estavam em igual condição dos bispos e presbíteros delegados. A esses coube a tarefa de votar e aprovar o resultado do trabalho, em nome da Igreja.

Embora a questão das mulheres não tenha sido desenvolvida em Medellín, e isto constitui um dos seus limites, elas atuaram ativamente no processo. Não somente na infraestrutura, logística e organização. As 13 mulheres presentes participaram com voz e voto nas comissões que redigiram os documentos. Elas "se fizeram sujeitos", com firmeza e bom humor, apesar do peso da herança patriarcal. Vale a pena conferir o nome, a atuação e a história de vida delas, apresentada por Maria Cecília Domezi (DOMEZI, 2018, p. 86-97).

\section{3 "Filha" do Vaticano II}

A conferência de Medellín foi convocada para concretizar o Concílio Vaticano II na América Latina. Um olhar panorâmico sobre os documentos do Concílio e de Medellín identifica que não aconteceu uma mera aplicação. Medellín apreende as mais significativas contribuições do Concílio, mas não faz uma leitura literal, ou uma mera transposição, de forma subordinada. Ao contrário, acontece um processo de discernimento, assimilação criativa e abertura de novas trilhas.

A imagem utilizada por Libanio para Medellín também serve para o Vaticano II. O concílio se tornou o evento eclesial mais importante do século XX para a Igreja católica, sensibilizando também alguns ramos das Igrejas protestantes, devido ao seu caráter ecumênico. E mais de 50 anos depois, continua sendo um símbolo de mudança permanente (eclesia semper reformanda), volta às fontes do cristianismo, diálogo com o mundo, articulação de Tradição com inovação. Por isso se entende porque grupos conservadores não aceitaram o Concílio. Outros, para diminuir sua força impulsionadora, distinguem o Vaticano II histórico do movimento de renovação que se seguiu a ele. Ao primeiro, atribuem 
alguma legitimidade. Ao segundo, lançam a pecha de "exageros", "perda do sentido religioso", "responsável pelo caos na Igreja”, “perda dos valores tradicionais” etc.

Ao contemplar o Vaticano II, como história e símbolo, alguns aspectos relevantes veem à tona. Sem ter a pretensão de exaurir os múltiplos significados e sementes de transformação do concílio, apontaremos de forma breve algumas convicções emanadas dele, referentes ao perfil da Igreja e de sua ação pastoral, com os respectivos documentos.

- A Igreja se constitui como Povo de Deus, sinal de salvação para o mundo. A partir desta identidade e missão se configuram os diferentes ministérios e serviços eclesiais: bispos, presbíteros, leigos (as) e religiosos (as). O primado petrino, reservado ao Papa, se articula com a colegialidade (Constituição dogmática Lumen Gentium).

- Com isso, os leigos saem da posição de "filhos menores" da Igreja, para serem membros atuantes, na comunidade eclesial e também na sociedade (Constituição Lumen Gentium e Decreto Apostolicam Actuositatem).

- Os institutos religiosos de Vida Consagrada são convocados a "voltar às fontes" dos carismas fundacionais e rever seu estilo de vida e missão (Decreto Perfectae Caritatis).

- A Igreja em diálogo com o mundo contemporâneo, realiza uma leitura pastoral dos "Sinais dos Tempos", para identificar as oportunidades e as ameaças para uma atuação pastoral eficaz, em vista da transformação da sociedade segundo o projeto de Jesus Cristo (Constituição Pastoral Gaudium et Spes).

- A Bíblia ocupa lugar central na vida cristã. Recoloca-se a partir daí a clássica questão da legitimidade da Tradição para a definição da doutrina, e sua relação com a Escritura. Destaca-se a importância da Bíblia para a teologia (Constituição dogmática Dei Verbum). 
- Deve-se promover uma renovação na liturgia, de forma que, ao abandonar formas anacrônicas, ela expresse a realidade da Igreja como Povo de Deus, fomente a participação dos fiéis e unifique "Palavra" e "Sacramento (Constituição Dogmática Sacrossantum Concilium).

- A formação teológica (que na época era reservada somente aos clérigos) percorrerá o caminho de: partir da Bíblia e da patrística, enriquecer-se com a Tradição, legitimada nos Concílios e documentos papais, ser sistematizada com precisão conceitual, e comunicada de forma significativa para o nosso tempo (Decreto Optatum Totius)

- A Igreja Católica é chamada a estabelecer uma relação dialogal (e não mais de combate) com as outras confissões cristãs, no nível da espiritualidade, do núcleo comum da doutrina e do exercício da caridade (Decreto Unitatis Redintegratio).

- Cultive-se uma postura de respeito pelas outras religiões, reconhecendo a misteriosa ação de Deus nelas e nos seus membros (Decreto Nostra Aetate).

- Dada sua importância para o mundo contemporâneo, a educação cristã ministrada nas instituições educativas, deverá ser renovada nos seus objetivos e métodos (Declaração Gravissimum Educacionis)

- O mundo da comunicação social é um novo desafio a abre possibilidades de evangelização (Decreto Inter Mirifica).

- A Igreja é chamada a evangelizar para além de suas fronteiras tradicionais, em perspectiva missionária (Decreto Ad Gentes).

Medellín se realiza no ardor da recepção do Vaticano II, três anos após a sua conclusão, em meio ao fascínio e às resistências que esse suscitou. 


\section{Recepção criativa e criadora a partir do Concílio}

Por iniciativa de um pequeno grupo de bispos "progressistas”, Medellín foi convocada para "aplicar” o Concílio na América Latina. Mas não fez isso de maneira mecânica, superficial ou infantilizada. De fato, fez uma releitura e abriu novas perspectivas. A Conferência não pode ser comparada ao Concílio, em termos de amplidão, abrangência, tempo de realização e representatividade. Antes, Medellín é filha jovem do Vaticano II, que cultiva relação filial e caminha para a adultez. Ela criou seu perfil próprio, mantendo os vínculos. Com vigor juvenil, moveu-se com mais rapidez do que a mãe. Aprendendo o longo caminho de praticamente quatro anos do concílio, Medellín realizou breve síntese e inovadora reflexão, no curto prazo de 10 dias.

As "conclusões de Medellín” (CELAM, 2010) compõem-se de textos introdutórios e dos 16 documentos, elaborado pelas comissões, discutidos e votados em plenário. No que diz respeito aos primeiros, constam: (1) Apresentação do presidente e do secretário geral do CELAM, (2) Discurso de abertura de Paulo VI, (3) Mensagem dos bispos aos povos da América Latina, (4) Introdução aos documentos.

Os documentos estão dispostos em três blocos ou eixos, com os respectivos temas:

I. Promoção Humana: (1) Justiça, (2) Paz, (3) Família e Demografia, (4) Educação, (5) Juventude.

II. Evangelização e crescimento na Fé: (6) Pastoral Popular, (7) Pastoral das Elites, (8) Catequese, (9) Liturgia.

III. Igreja visível e suas estruturas: (10) Movimento de leigos, (11) Sacerdotes, (12) Religiosos, (13) Formação do clero, (14) Pobreza da Igreja, (15) Pastoral de Conjunto, (16) Meios de Comunicação Social. 
Esta disposição de vários documentos compondo um texto oficial, plural na temática e convergente nos resultados, leva os comentaristas, quando citam Medellín, a utilizar o nome específico de cada documento e o parágrafo em questão (por exemplo, Justiça, 21), ou o número a ele correspondente (Medellín, I, 21). Neste artigo, adotaremos a primeira opção.

Medellín assumiu com liberdade e discernimento o Vaticano II, conforme o que se percebia na época como os grandes clamores de Deus na realidade latinoamericana, como a justiça social, a paz e o desenvolvimento integral. Por esse motivo, não há uma mera correspondência entre cada documento do Concílio e os da Conferência. Então, qual se destaca mais?

Diferentemente do Concílio, que elaborou, discutiu e aprovou cada documento em separado, em várias sessões, da Sacrosanctum Concilium (1963) à Gaudium et Spes (1965), entremeado por largo espaço de tempo, Medellín realizou um trabalho simultâneo com as 16 comissões, em apenas 10 dias.

Sem dúvida, a Gaudium et Spes constitui o documento que mais repercutiu em Medellín. Salta à vista o expressivo número de citações dessa constituição pastoral. Parte do espírito que animou a Conferência provém das grandes intuições da Gaudium et Spes: dialogar com a sociedade contemporânea, ler os Sinais dos Tempos à luz da fé, assumir atitudes de compromisso para transformar o mundo.

Diríamos que Medellín realizou, antecipadamente, o sonho do Papa Francisco, de uma "Igreja em saída". Até na disposição dos textos se manifesta tal postura. Os documentos da Conferência, colocados no primeiro bloco - Justiça, Paz, Família e Demografia, Educação e Juventude - começam com questões sociais e culturais, em vista da promoção humana. Manifesta a opção de começar a reflexão ouvindo os apelos de Deus no mundo. Uma Igreja extro-vertida!

Curiosamente, o último documento, "Meios de Comunicação Social", aparece no terceiro bloco ou eixo, que contempla a revisão das estruturas da Igreja. 
Poderia estar na primeira parte. Aqui também se vê como Medellín foi visionária. Ela sustenta que as mídias - que naquele tempo eram os jornais, revistas, rádio e TV - não consistem somente em um espaço para evangelizar, mas algo que incide diretamente nas transformações em curso no continente latino-americano.

Qual é a principal novidade de Medellín? Comentaristas abalizados, como o historiador Oscar Beozzo, apontam a leitura dos Sinais dos Tempos, com o método Ver-Julgar-Agir, como o mais original da Conferência. De fato, a Gaudium et Spes proclamava:

A Igreja, a todo momento, tem o dever de perscrutar os sinais dos tempos e interpretá-los à luz do Evangelho, de tal modo que possa responder, de maneira adaptada a cada geração, às interrogações (..) sobre o significado da vida presente e futura e de suas relações mútuas”. (GS 4).

Em Medellín, a evangelização conecta-se com os Sinais dos tempos, que observados em nosso continente sobretudo na área social, constituem um "dado teológico” e interpelação de Deus (Pastoral das Elites, 13). A ação pastoral realizada nos espaços onde acontecem os processos de libertação e humanização da sociedade, adotará "uma pedagogia baseada no discernimento dos sinais dos tempos, na trama dos acontecimentos” (Movimento de Leigos 13).

O método Ver-Julgar-Agir é adotado por quase todos as comissões da Assembleia e está explícito nos documentos por ela discutidos e aprovados. É bom recordar que tal método foi criado pelo Movimento Internacional da Ação Católica, fundado pelo belga Josef León Cardijn, na década de 30, e tinha como principal finalidade formar lideranças cristãs para atuar como fermento na sociedade. Posteriormente, foi assumido por João XXIII na Mater et Magister. Vejamos como ele aparece em Medellín. 


\section{VER a realidade para DISCERNIR à luz da fé}

\subsection{0 momento do "VER"}

"Ver" não consiste em reunir um ou mais fatos, tomados de maneira isolada ou justaposta. Mas sim em uma análise crítica, desinstaladora e inquietante, utilizando instrumentais sobretudo das ciências humanas e sociais. Nos diferentes documentos de Medellín, o momento do Ver é nomeado de diferentes formas, como: "Fatos" (Justiça 1-2, Movimento de leigos 1-6), "situação" (Paz 1-11, Família 2-3, Juventude 1-9), ou "realidade" (Formação do Clero 1-3, Pobreza na Igreja 1-3).

No contexto de cada documento, o momento do VER geralmente ocupa um breve espaço, como exceção do tema da Paz. Não se detém em análises longas. Essas são incisivas, diretas, sem meias palavras, ou "excesso de prudência" que caracteriza certas posturas eclesiásticas. Assim, é inverossímil a afirmação que Medellín "fala demais da realidade e pouco de Deus".

Na Conferência de Puebla (1979), o momento do VER sofreu uma redução e foi quase abandonado, devido à pressão do Vaticano. Argumentava-se, entre outras coisas, que tal método, ao começar da realidade - e não da doutrina- condicionaria a leitura teológica e direcionaria (para a esquerda..) as opções pastorais da Igreja. Ao partir de uma visão crítica da realidade, lida em chave social, Medellín põe a Igreja numa "boa crise", pois a inquieta e exige mudança de posturas.

Medellín adota termos da sociologia crítica. O que importa não é um mero jogo de palavras. E sim, a compreensão da realidade social que supera a ingenuidade e desvela os conflitos sociais e suas causas. Por exemplo, no documento sobre a Paz: "formas de opressão", "setores dominantes" e "setores oprimidos" ou "marginalizados" (Paz 5,6,7), "justificativas ideológicas" (Paz 6), "neocolonialismo interno" (Paz 2) e externo (Paz 8), "imperialismo internacional do dinheiro" (Paz 9e), "violência institucionalizada" (Paz 16), "manutenção dos privilégios" dos mais ricos (Paz 17), "povo conscientizado e organizado" (Paz 19), 
“sadio espírito crítico” (Paz 25), “organizações de base para reivindicar e consolidar direitos” (Paz 27), “defender o direito dos pobres e oprimidos (Paz 22).

As expressões estão relacionadas como uma visão sistêmica da sociedade, que sofreu certa “neutralização” em Puebla e se abandonou em Santo Domingo. Tal visão crítica da sociedade foi retomada e atualizada em Aparecida. Posteriormente, faz parte do ensino do Papa Francisco, especialmente na Laudato Si' (cap III e IV), na Evangelii Gaudium (cap IV) e nas mensagens nos Encontros Mundiais dos Movimentos Populares. Aqui reside uma das causas de resistência em propagar o documento de Medellín na atualidade. Ele é incisivo, descortina sem meias palavras as causas políticas, econômicas e sociais que até hoje mantém a pobreza e a marginalização no nosso continente.

\subsection{Julgar}

O segundo momento do método consiste em confrontar a visão da realidade com o olhar da fé cristã. Para isso, recorre-se à Bíblia, à Tradição da Igreja e ao Magistério. Não se trata de emitir um juízo qualquer, e sim de discernir os sinais da presença e da ausência de Deus. E daí, ouvir o que Ele nos oferece como Revelação e Graça. Escutar os apelos de conversão. Ora, acusa-se Medellín (e consequentemente, a teologia da Libertação) de fazer uma leitura sociológica e reducionista da fé cristã, pois o julgar já estaria condicionado pelos instrumentais do momento anterior, o de VER.

Acontece que, ao ler os fatos e suas causa com a Luz divina, a realidade ganha novo sentido e se abrem perspectivas inusitadas de solução. No dizer da Gaudium et Spes:

O Povo de Deus, movido pela fé e conduzido pelo Espírito do Senhor que enche o face da terra, esforça-se por discernir nos acontecimentos, nas exigências e nas aspirações de nossos tempos, em que participa com os outros homens, quais sejam os sinais verdadeiros da presença ou dos desígnios de Deus. A fé, com efeito, esclarece todas as coisas com luz nova. Manifesta o plano divino sobre a vocação integral do homem. E por isso orienta a mente para soluções plenamente humanas. (GS 11). 
Ora, ao fazer o movimento de confrontar a realidade com a Palavra de Deus na Tradição eclesial, a comunidade cristã refontiza-se. Buscando os sinais de Deus na história, encontra o próprio Deus, inefável e inesgotável. Parafreseando o teólogo alemão Karl Rahner, ao refletir com a luz do Deus vivo manifestado em Jesus na história, descobrimos Deus em si mesmo. A doutrina ganha novos significados. Pois o que sabemos de Deus se dirige para a redenção do ser humano e do cosmos.

O momento do julgar faz-se presente em praticamente em todos documentos de Medellín. É denominado com diferentes termos, como: fundamento doutrinal (Justiça 3-5); reflexão doutrinal (Paz 14 - Concepção cristã da paz); Papel da família (Família 4-11); Sentido humanista e cristão da educação (Educação 8-9); Critérios para orientação pastoral (Juventude 10-12); Princípios teológicos (Pastoral Popular 5-9); Fundamentação teológica e pastoral (Liturgia 27); Critérios teológico-pastorais (Movimento de Leigos 7-12); Elementos de reflexão pastoral (Sacerdotes 12-15); Missão do Religioso e Atualização (Religiosos 1-9, que mistura o VER e o JULGAR); Pressuposto teológico (Formação do Clero 7); Motivação doutrinal (Pobreza na Igreja 4-7); Orientações doutrinais (Pastoral de Conjunto 5-9); e Justificação (Meios de Comunicação Social 4-9). Por vezes, acentua-se a reflexão de cunho pastoral. Outras vezes, convicções da doutrina cristã, ou ambas.

Medellín cita poucos textos bíblicos, e isso constitui um limite histórico. Até certas palavras específicas são pouco utilizadas, como: bíblia (1x), bíblico/bíblica (5x), Palavra de Deus (7x). De outro lado, abundam as citações da Gaudium et Spes e da Populorum Progressio, de Paulo VI. Tal escolha se justifica pela necessidade de respaldar as opções da Conferência com o Concílio e com esse importante Documento Pontifício do Ensino Social da Igreja, lançado em março de 1967.

Se o Medellín histórico não recorre a muitos trechos bíblicos, nem cita o documento conciliar Dei Verbum sobre a Palavra de Deus, o Medellín práxis pastoral está fundado na leitura comunitária e libertadora da Bíblia. Essa é uma 
das "pedras de toque" da Igreja dos pobres e da Teologia da Libertação, que surgiu de Medellín. As Comunidades Eclesiais de Base se desenvolveram a partir Círculos Bíblicos. As reflexões teológicas latino-americanas, não somente a teologia bíblica, mas também a ética e a sistemática bebem da fonte da Sagrada Escritura, "alma de toda a teologia” (DV 24).

\section{AGIR para transformar a sociedade e a Igreja}

O terceiro momento do método consiste em mobilizar pessoas e recursos para deslanchar processos de mudança, em coerência com os passos anteriores (analisar a realidade em questão e refletir sobre ela à luz da fé). Aqui nos deparamos com duas questões diferentes e complementares, no que diz respeito à Medellín. A primeira consiste em verificar se os documentos conclusivos foram consequentes, ao sugerir práticas e processos pastorais exequíveis. Um dos limites mais comuns nos planejamentos das instituições (especialmente as religiosas) consiste em se limitar às "boas intenções", ou a elencar muitas atividades dispersas, sem explicitar com clareza os prazos, as metas, os indicadores, os custos e as pessoas encarregadas.

Entregou-se às Conferências Episcopais nacionais a missão de colocar em prática as orientações de Medellín, atendendo às necessidades próprias e a urgência de cada país (Planejamento pastoral 27). O presidente e o secretário do CELAM, respectivamente Dom Avelar Brandão e Dom Eduardo Pirónio, ao apresentarem as Conclusões de Medellín, em novembro de 1968, insistiram:

Agora começa a tarefa de aprofundamento, divulgação e realização. Tratase de estudar a fundo as conclusões adotadas, fazê-las conhecer a todo o Povo de Deus e comprometer sua progressiva aplicação (...). O compromisso não é apenas dos bispos. É de todo o povo de Deus que, nesta hora providencial do continente, experimenta o chamado do Espírito. A resposta exige profundidade na oração, maturidade nas decisões, generosidade nas tarefas. (CELAM, 2010, p. 6-7).

Vale recordar que alguns bispos, como Dom José Maria Pires, na Paraíba, começaram a implantar as mudanças propostas por Medellín logo que chegaram da 
Assembleia. Mas, no Brasil, a Conferência ficou mais conhecida entre os agentes de pastoral após Puebla. Isso se deve em parte ao fato de que no mesmo ano de Medellín aconteceu o recrudescimento do regime militar. E a CNBB começou a tomar posição crítica diante do regime a partir de 1972, com o clássico documento dos bispos do nordeste "Ouvi os clamores do meu povo". Mais tarde, teólogos da libertação e pastoralistas propiciariam uma leitura positiva de Puebla, colocando-a como continuidade de Medellín. Tanto que desde aquela época se fala em "Medellín-Puebla".

A segunda questão diz respeito a como se implantaram as propostas de Medellín e como elas foram avaliadas nas conferências seguintes (Puebla, Santo Domingo e Aparecida). Ambas questões exigem um estudo aprofundado, impossível de se realizar no presente artigo. Algo se pode afirmar, a respeito de processos de avaliação entre as Conferências, a partir de Medellín. Já em Puebla, devido ao contexto eclesial complexo e conflituoso, não se partiu das conclusões de Medellín e nem se fez uma avaliação séria, considerando as conquistas e os limites do caminho percorrido. Isso fez com que muitas preciosidades de Medellín se perdessem no caminho. Buscaram-se novas soluções pastorais em Puebla, enquanto muitas delas já estavam em Medellín.

Praticamente todos os documentos de Medellín concluem-se com as orientações pastorais. A qualidade delas não é uniforme, nem na extensão, nem na exequibilidade. Os documentos mais citados e relembrados anos depois são: Justiça, Paz, Educação, Juventude, Catequese, Pobreza na Igreja e Pastoral de Conjunto.

Diferentes termos e configurações são adotados pelos documentos de Medellín, no que diz respeito ao AGIR. O caráter das ações e dos processos sugeridos em cada um está de acordo com o bloco ou eixo temático ao qual pertence. 


\subsection{Eixo 1: promoção humana}

O documento Justiça sugere várias iniciativas. Utiliza o termo "Projeções da pastoral social”, onde se delineia a “orientação das mudanças sociais” para: família, organizações profissionais, empresas e economia e organização dos trabalhadores, em unidade de Ação. Acrescenta-se ainda "reforma política”, e "informação e conscientização" (n. 6-23). O documento Paz apresenta breves "conclusões pastorais" (n. 20-32).

Os documentos Justiça e Paz constituem uma unidade e tematizam, com clareza, a opção pelos pobres. Trata-se de uma mudança de postura da Igreja: assumir a causa dos oprimidos e intervir na sociedade, não a partir de conchavos com o poder político e econômico, e sim atuando na sociedade civil e suas instâncias. Não mais centrado na ação exclusiva da autoridade eclesiástica, e sim na comunidade eclesial. Sobretudo os leigos (as) devem atuar nas diversas instâncias da sociedade civil. Ao mesmo tempo, sua ação é respaldada pela palavra profética dos bispos, que denunciam a violência e as injustiças, e anunciam uma sociedade justa e solidária.

O documento Educação deixou marcas indeléveis na prática eclesial. Ele incorporou a concepção de educação libertadora, baseada em Paulo Freire. Essa se tornou uma palavra-chave que impulsionou processos de formação de padres, religiosos (as) e leigos (as). Rompeu os limites do ambiente escolar. Tornou-se um princípio educativo que perpassa toda a pastoral. A ele se liga o neologismo “conscientização", também criado por Paulo Freire. Segundo esse renomado educador brasileiro, a consciência sempre se desenvolve na relação do ser humano, em comunidade, com o mundo. Os processos educativos libertadores visam ajudar as pessoas, especialmente os pobres, a passarem de uma consciência ingênua para a consciência crítica (FREIRE, 1979).

Já Família e Demografia faz algumas "Recomendações para uma pastoral familiar” (n. 12-21). O documento Educação traça “orientações pastorais”. Nelas se 
incluem as linhas gerais e as orientações específicas para a escola e a universidade católica. E termina com algumas observações acerca do planejamento (n.10-31). O documento Juventude oferece "Recomendações Pastorais", com relação à juventude em geral e aos movimentos juvenis (n.13-20).

\subsection{Eixo 2: evangelização e crescimento na fé}

Esse eixo toca o núcleo da missão da Igreja e dos seus processos internos. Tal tarefa essencial visa possibilitar "a renovada pastoral popular e das elites, a uma catequese viva e orgânica, a uma liturgia frutífera e expressiva” (CELAM, 2010, p. 7).

No que tange à Pastoral Popular, há também "Recomendações pastorais” (n.10-15). Já Pastoral das elites distingue as de caráter geral e de caráter especial. Nesse âmbito, citam-se: artistas e pessoas de letras, estudantes universitários, grupos socioeconômicos, poderes militares e poderes políticos (n. 14-21).

O documento Catequese segue outro esquema. O foco situa-se na mudança do conteúdo e da metodologia. Por isso, VER e JULGAR são apresentados como "necessidade da renovação" e "caraterísticas da renovação" (n. 1-5). Enquanto que o AGIR delineia Prioridades e Meios para a renovação catequética, encerrando-se com as Conclusões (n. 6-17). Importa ressaltar que este documento, tão breve quanto denso, teve enorme impacto na pastoral do Brasil, com a implantação da Catequese Renovada em Comunidades, Paróquias, Dioceses e Regionais. E recebeu um documento da CNBB, intitulado “Catequese renovada. Orientações e conteúdo” (CNBB, 1983). Por fim, o documento Liturgia faz recomendações pastorais pertinentes, de acordo com o espírito da Sacrosanctum Concilium, ao bispo, às Conferências Episcopais, e aos Serviços do CELAM. Encerra-se com "sugestões particulares" (n. 8-15). 


\subsection{Eixo 3: Igreja visível e suas estruturas}

No Movimento dos leigos, há breves "recomendações pastorais" e a moção acerca da implantação de um Conselho Continental dos leigos (n.13-19). O documento Sacerdotes oferece "algumas conclusões orientadoras" no que diz respeito à espiritualidade, diferentes formas de exercer o ministério, diálogo e cooperação, atualização cultural e estilo de vida simples (n.20-27). Já o documento Formação do Clero traça um perfil do presbítero que se pretende formar, tais como: ouvinte da Palavra de Deus, vivência dos conselhos evangélicos, espírito de serviço, entrega a Cristo, disciplina, formação intelectual e pastoral, atratividade vocacional, capacidade de interpretar os sinais dos tempos (n.8-33).

O documento Religiosos segue outro esquema. Os três momentos do método estão misturados. Inicialmente se apresenta a singularidade dos consagrados (as) enquanto "missão profética e testemunho escatológico" (n.2). Solicita-se que eles e elas encarnem-se no mundo real e estejam inseridos na Pastoral de Conjunto (n.36), façam uma revisão séria e metódica de suas estruturas (n.7-9), e contribuam para o desenvolvimento integral do ser humano (n.10). Daí seguem algumas recomendações e orientações (n.11-13). Insiste-se no envolvimento na pastoral de Conjunto, na atuação com os leigos e no bom relacionamento com os bispos (n.1430).

Convém lembrar que o documento Religiosos não está no rol dos mais inspiradores em Medellín. Surpreendentemente, foram os consagrados, especialmente as mulheres, as que implantaram grandes processos de renovação interna, renunciaram às obras clássicas e fundaram comunidade inseridas nos meios populares rurais e urbanos. $\mathrm{O}$ apelo às comunidades religiosas em relação aos pobres se encontra em outro documento:

As comunidades religiosas, por especial vocação, devem dar testemunho da pobreza de Cristo. Recebam nosso estímulo as que se sintam chamadas a formar, entre seus membros, pequenas comunidades, encarnadas realmente nos ambientes pobres; serão um chamado contínuo à pobreza evangélica dirigido a todo o Povo de Deus. (Pobreza na Igreja, 16).

Horizonte, Belo Horizonte, v. 16, n. 50, p. 600-631, maio/ago. 2018 - ISSN 2175-5841 
Também na primeira geração dos teólogos da libertação predominavam os religiosos. A CLAR (Conferência Latino Americana dos Religiosos) e as Conferências nacionais levaram adiante as decisões de Medellín com ousadia e liberdade. É um caso emblemático em que a Medellín simbólica e a práxica foram além do evento histórico.

O último documento de Medellín, na ordem de apresentação, denomina-se Meios de Comunicação Social. Parece que foi incluído no terceiro bloco (estruturas da Igreja), porque não se encontrou outro lugar conveniente. Acertadamente, a conferência tratou deste tema, abordado no Vaticano II no decreto Inter Mirifica. E desde o início, reconhece que as Mídias, como as denominamos hoje, não são simplesmente "meios", e sim uma das principais dimensões da humanidade. Elas inauguram uma nova época, produzem impacto crescente à medida que a tecnociência ganha espaço. Abrangem a pessoa em sua totalidade, plasmam o ser humano e a sociedade. Forjam uma nova cultura (Comunicação Social 1). As "recomendações pastorais" são assertivas. Por exemplo: manter os meios próprios, desde que sejam eficazes e prestem um serviço real à comunidade; capacitar leigos, religiosos, presbíteros e bispos; promover vocações laicais neste campo; privilegiar o público-alvo juvenil direcionar-se para efetiva promoção das comunidades; incentivar a liberdade de expressão na Igreja (n.10-24). E conclui: é imprescindível atuar nas mídias, em todos os níveis e em todas as formas, na ação pastoral da igreja, para alcançar os fins que a Assembleia propôs (n.24).

Os outros dois documentos do terceiro eixo, Pobreza na Igreja e Pastoral de Conjunto, merecem destaque, devido à sua originalidade e incisividade. Não somente pelo momento do AGIR, e sim pela sua totalidade. Faremos um breve comentário sobre o tema da Pobreza. 


\section{Uma Igreja que opta pelos pobres e celebra a vida}

\subsection{O desafio da Pobreza na Igreja}

O documento Pobreza na Igreja é de grande atualidade. Inicialmente, constata que a pobreza real de grande parte da população é consequência de estruturas injustas. E isso exige dos bispos "deixar-se tocar" por tal situação. Não permanecer indiferentes ante as tremendas injustiças sociais na América Latina, que mantêm a maioria de nossos povos numa dolorosa pobreza, que em muitos casos chega a ser miséria desumana (Pobreza na Igreja 1). A isso se acrescenta um vasto contingente de pessoas analfabetas, sem acesso à educação e colocadas à margem da cultura. Tal situação "é uma escravidão inumana. Sua libertação, uma responsabilidade de todos os homens latino-americanos" (Educação 3).

O documento Justiça converge no mesmo parecer, realçando que a indignação diante da injustiça remonta ao próprio Deus. "Essa miséria, como fato coletivo, que marginaliza grandes grupos humanos em nossos povos, se qualifica de injustiça que clama aos céus" (Justiça 1).

$\mathrm{Na}$ mesma linha, afirma-se que o subdesenvolvimento é uma injusta situação promotora de tensões que conspiram contra a paz. A miséria, causada pelas injustiças sociais, "exprimem uma situação de pecado" (Paz 1).

Medellín, no Documento Pobreza na Igreja distingue: (a) a pobreza como carência de bens, um mal em si mesmo; (b) a pobreza espiritual, atitude de abertura para Deus; (c) a pobreza como compromisso em favor dos necessitados, para testemunhar o mal da pobreza material e o bem da liberdade espiritual perante as coisas. Neste contexto, uma Igreja pobre "prega e vive a pobreza espiritual como atitude de infância espiritual e abertura para o Senhor; e compromete-se ela mesma com a pobreza material” (Pobreza na Igreja 5). 
A pobreza da Igreja e de seus membros será assim um sinal do valor dos pobres aos olhos de Deus e um compromisso de solidariedade com os que sofrem. É tarefa urgente

[...] traduzir esse espírito de pobreza em gestos, atitudes e normas, que a tornem um sinal mais lúcido e autêntico do Senhor. A pobreza de tantos irmãos clama por justiça, solidariedade, testemunho, compromisso, esforço e superação para o cumprimento pleno da missão salvífica confiada por Cristo. (Pobreza na Igreja 7).

Esta postura clara se manifesta nas opções pastorais, que incluem: a preferência efetiva pelos pobres e o testemunho pessoal e comunitário, em vista de um serviço aos nossos povos (Pobreza na Igreja 8-18). Isso significa em primeiro lugar, a redistribuição de esforços e de pessoal apostólico, que vise preferencialmente os setores mais pobres e necessitados e os povos segregados (Pobreza na Igreja 9). Em segundo lugar, criar uma sintonia afetiva e efetiva com eles. Aproximar-se dos pobres cada vez com maior simplicidade e sincera fraternidade (idem). Então, dizem os bispos e delegados, "essa solidariedade implica em tornar nossos seus problemas e suas lutas e em saber falar por eles” (idem). E tal atitude se expressa em iniciativas públicas, com impacto na sociedade.

Isto há de se concretizar na denúncia da injustiça e da opressão, na luta contra a intolerável situação suportada frequentemente pelo pobre, na disposição de dialogar com os grupos responsáveis por essa situação, para fazê-los compreender suas obrigações. (Pobreza na Igreja 10).

A expressão “opção pelos pobres” não se encontra literalmente em Medellín. Mas os termos pobre/pobres aparecem ao menos 66 vezes. E a palavra pobreza, no mínimo 33 vezes. A expressão “opção preferencial pelos pobres” foi cunhada em Puebla, para reafirmar a continuidade com Medellín.

A Conferência de Puebla volta a assumir, com renovada esperança na força vivificadora do Espírito, a posição da II Conferência Geral que fez uma clara e profética opção preferencial e solidária pelos pobres, não obstante os desvios e interpretações com que alguns desvirtuaram o espírito de Medellín, e o desconhecimento e até mesmo a hostilidade de outros. Afirmamos a necessidade de conversão de toda a Igreja para uma opção preferencial pelos pobres, no intuito de sua integral libertação. (Puebla 1134). 
A assim chamada "opção pelos pobres" constitui, portanto, uma presença profética, em todos os níveis, em vista da construção de uma nova sociedade, mais justa, inclusiva e solidária. Da parte de Igreja, postula abandonar os privilégios acumulados durante séculos, e que a impediam de agir com liberdade. E colocar-se como humilde servidora. Trata-se de um projeto de vida, que renova o coração e a face da Igreja.

Queremos que nossa Igreja latino-americana esteja livre de peias temporais, de conveniências indevidas e de prestígio ambíguo; que (..) seja mais transparente e forte sua missão de serviço; que esteja presente na vida e nas tarefas temporais, refletindo a luz de Cristo, presente na construção do mundo. (Pobreza na Igreja 18).

\subsection{Liturgia e vida}

É comum ouvir nos círculos eclesiais (e eclesiásticos) que Medellín foi radical, pois se dedicou demasiadamente às questões sociais, e se esqueceu da espiritualidade, da oração e da liturgia. É verdade que a Assembleia enfatizou as questões sociais, pois elas foram percebidas como o grande clamor de Deus na realidade latino-americana. E também se deve levar em conta que na década de 60 o contexto cultural no ocidente era favorável ao antropocentrismo e à autonomia do humano, depois de séculos de domínio da Igreja e da religião sobre a sociedade (cristandade).

O documento Liturgia está situado no segundo eixo, referente à Evangelização Crescimento na fé. Basta se deter sobre ele, e perceber como a Assembleia tinha uma visão integral, que articula corretamente as três virtudes teologais (fé, esperança e caridade). Medellín deu orientações lúcidas sobre uma liturgia encarnada, bem fundamentada na doutrina cristã. Baseou-se em vários textos da Sacrosanctum Concilium e da Lumen Gentium.

O ítem "elementos doutrinais", que corresponde ao "Julgar" no método adotado resume as convicções básicas sobre a liturgia. Segundo o documento, "a presença do mistério da salvação, enquanto a humanidade peregrina até sua plena 
realização na parusia do Senhor, culmina na celebração da liturgia” (Liturgia 2). Corretamente, o documento reafirma que "a liturgia é ação de Cristo, Cabeça e de seu Corpo, que é a Igreja”. Ela integra a iniciativa da Trindade e a resposta da humanidade nos que se ligam pela fé e pela caridade (idem). E aí se descortina a segunda virtude teologal, dado seu caráter escatológico.

Como não vivemos ainda a plenitude do Reino, toda celebração litúrgica está essencialmente marcada pela tensão entre o que já é uma realidade e o que ainda não se verifica plenamente; é a imagem da Igreja, ao mesmo tempo santa e necessitada de purificação; tem um sentido de alegria e uma dolorosa consciência do pecado. Numa palavra, vive na esperança. (Liturgia 2).

O documento mostra a relação íntima entre celebrar e viver o amor solidário, evitando o espiritualismo escapista. O gesto litúrgico autêntico "implica um compromisso de caridade, um esforço sempre renovado por ter os sentimentos de Cristo Jesus, e para uma contínua conversão” (Liturgia 3).

Medellín, dentro da legítima tradição da Igreja, reafirma a importância da liturgia: "a instituição divina da liturgia jamais pode ser considerada como um adorno contingente da vida eclesial”, pois a comunidade cristã se edifica enraizada na celebração da Eucaristia, "pela qual se inicia toda a educação do espírito da comunidade" (idem).

A liturgia tanto é a plenitude de vida cristã, quanto estimula a sua realização, buscando integrar os distintos componentes da existência.

Esta celebração, para ser sincera e plena, deve conduzir tanto às várias obras de caridade e mútua ajuda como à ação missionária e às várias formas de testemunho cristão (...) [Ela] comporta e coroa um compromisso com a realidade humana, com o desenvolvimento e com a promoção, precisamente porque toda a criação está envolvida pelo desígnio salvador que abrange a totalidade do homem. (Liturgia 3-4).

O documento expõe então uns "princípios pastorais" (n.5-7). Nesses se fortalece a convicção de que a liturgia propicia o encontro de Deus com o cristão e sua comunidade. Ela manifesta a adesão a Jesus e impele para o compromisso 
transformador. Enquanto presença do mistério da salvação, a liturgia visa em primeiro lugar a glória de Deus. Por sua vez, essa mesma glória se comunica a nós. Destarte a celebração litúrgica, mediante o conjunto de sinais com que expressa a fé, comporta as seguintes dimensões: conhecimento e vivência mais profunda da fé; um sentido da transcendência da vocação humana, o fortalecimento do espírito da comunidade; uma mensagem cristã de alegria e esperança; a dimensão missionária da vida eclesial; e a exigência de comprometer-se com as realidades humanas (Liturgia 6).

Todas essas dimensões devem se realizar, simultaneamente. Para isso, é necessário que a comunidade eclesial assuma procedimentos e atitudes, assim delineados:

1. (Promover) uma catequese sobre o mistério cristão e sua expressão litúrgica;

2. Adaptar-se ao gênio das diversas culturas e encarnar-se nele;

3. Acolher positivamente a pluralidade na unidade, evitando erigir, a priori, a uniformidade como princípio;

4. Acompanhar tudo o que houver de são no processo de evolução da humanidade;

5. Conduzir a uma experiência vital da união entre a fé, a liturgia e a vida cotidiana. (Liturgia 7).

As "recomendações pastorais", que se seguem, são lúcidas e equilibradas. Evitam o extremo do rigorismo das normas, da falta de respeito pelo sagrado, ou de instrumentalização da liturgia. Elas salientam a responsabilidade do bispo em promover a vida litúrgica na Igreja local, estabelecer as regras necessárias, atuar em conjunto com uma comissão composta de estudiosos da liturgia, Bíblia, pastoral, música e arte sacra (Liturgia 8).

Às Conferências Episcopais dos diversos países do continente cabe a função regulamentadora e coordenadora, dentro dos limites estabelecidos, que assegurem a dupla fidelidade à sua realidade local e à Igreja universal. Para isso, Medellín recomenda que estas tenham maior delegação para promover as adaptações necessárias, de acordo com as necessidades e as culturas regionais, que então serão apresentadas à Santa Sé (Liturgia 9-10). 
Sugere-se também o incremento de serviços do Departamento de Liturgia do CELAM, na linha de informação, documentação, coordenação, pesquisa e formação. Esse trabalho reunirá "experts" não somente da liturgia, como também da Bíblia, da Pastoral e das ciências antropológicas, "cujos trabalhos abram caminho a um progresso legítimo" (Liturgia 11,b). E além disso:

um escritório de coordenação dos musicólogos, artistas e compositores numa união de esforços que se estejam realizando em nossos países, de forma a proporcionar uma música digna dos sagrados mistérios. (Liturgia $11, c)$.

O documento elenca ainda as "Sugestões particulares":

- Celebração da Eucaristia em pequenos grupos e comunidades de base, que pode ter verdadeira eficácia pastoral;

- Estabelecimento, planificação e intensificação de pastoral sacramental comunitária mediante preparações sérias, graduais e adequadas para os sacramentos de iniciação cristã e o matrimônio;

- Celebração comunitária da penitência, pois contribui para ressaltar a dimensão eclesial desse sacramento e torna mais frutuoso a participação nele;

- Celebrações da Palavra, inclusive as com outras Igrejas cristãs;

- Buscar formas mais adequadas para as devoções populares, que lhes deem conteúdo litúrgico, de modo que se tornem veículos da fé e de compromisso com Deus e as pessoas (Liturgia 12-15).

Quem afirma que Medellín valorizou demasiadamente a práxis transformadora em detrimento da liturgia, fala de algo que desconhece. Por que esse olhar depreciativo sobre Medellín, em nome do "respeito ao sagrado", enquanto se ignoram certos desvios na liturgia e na devoção, transformadas em espetáculo midiáticos? A busca de atrair as multidões a todo custo está na direção oposta ao caminho traçado em Medellín. 
A Conferência articulou de maneira inovadora e original a dimensão social da fé e a opção pelos pobres com o culto divino, compreendendo assim o valor legítimo da liturgia e do cultivo da espiritualidade.

\section{Conclusões abertas}

A título de conclusão, elencaremos de forma lapidar alguns aspectos de Medellín, enquanto história, símbolo e práxis histórica, que são significativos para o caminhar da Igreja (e das igrejas) no nosso continente. Resumiremos as questões centrais abordadas neste artigo e acrescentaremos outras, já desenvolvidas nas duas obras citadas (GODOY; AQUINO JÚNIOR, 2017; SOUZA; SBARTELOTTI, 2018).

a) A Conferência de Medellín, acontecida em 1968, carrega os limites do seu tempo e da finitude de qualquer evento histórico. Verdadeiramente caracterizada como um Pentecostes na Igreja católica latino-americana, significou um grande avanço, mas esbarrou na “consciência possível”. As questões específicas ecológicas, de gênero, e étnico-culturais dos povos indígenas e afrodescendentes não foram suficientemente contempladas. De outro lado, seria anacronismo esperar de Medellín clareza sobre aspectos humanos que ainda estavam em gérmen. A causa ecológica, por exemplo, dava seus primeiros passos no mundo e a consciência planetária eclodiu com intensidade somente alguns anos depois. Mesmo com estes limites, Medellín significou um salto qualitativo na consciência eclesial, que sustentou a renovação da Igreja no nosso continente.

b) Graças a Medellín, em muitas regiões do continente, a Igreja floresceu. Entre seus frutos manifestos destacam-se a Teologia da Libertação e a Igreja dos Pobres. Mas não só. Podemos ainda enumerar: a Pastoral da Juventude, a Catequese renovada, as comunidades religiosas inseridas, o trabalho com lideranças formadoras de opinião, as múltiplas pastorais sociais, a formação comunitária para os sacramentos de iniciação cristã, a liturgia participada, os círculos bíblicos, a constituição dos Conselhos com leigos em várias instâncias, 
experiências relevantes de educação libertadora em instituições de ensino. Do ponto de vista da sociedade civil, elenca-se a participação efetiva de setores progressistas da Igreja em movimentos sociais e na política, rompendo uma aliança secular com as oligarquias.

c) O destemor da Conferência de Medellín diante das estruturas de pecado que geram e mantém a pobreza não se reduziu às palavras. Em vários lugares do continente, centenas e até milhares de cristãos deram vida em favor dos outros. A começar das lideranças de comunidades e catequistas, indígenas e afrodescendentes, barbaramente assassinadas pelos regimes militares e os poderes constituídos. Como também presbíteros, religiosos/as e Dom Oscar Romero. Tal "nuvem de testemunhas" ( $\mathrm{Hb}$ 12,1), de mártires da fé e da justiça, são um sinal eloquente da generosidade sem par; de quem, seguindo o exemplo de Jesus, dá a vida para que a Vida renasça.

d) Medellín continua sendo um exemplo bem-sucedido de Assembleia participativa, com resultados admiráveis. Tornou-se um sinal eloquente de que a Igreja precisa retomar processos participativos e superar o clericalismo, o autoritarismo e as decisões monocráticas. Ela inaugurou um processo de discussão, discernimento, planejamento e execução, que se estendeu em várias pastorais, paróquias, dioceses e regionais. Apontou procedimentos imprescindíveis para uma atuação organizada, orgânica e sistemática da ação evangelizadora. Afirmou, sem meias palavras: a revisão e renovação das estruturas eclesiais, no que têm de reformável, deve ser feita para atender as exigências de situações históricas concretas, tendo em vista a natureza da Igreja (Pastoral de Conjunto 5). Solicitou uma abertura das estruturas em várias instâncias. E para que essa seja efetiva, "é necessário uma comunicação real, ascendente e descendente, entre a base e a cúpula" (Pastoral de conjunto 8).

e) O método Ver-Julgar-Agir, adotado por Medellín, não é uma grade que aprisiona, nem um canal estreito que reduziria a liberdade soberana da Palavra de Deus. E ele pode ser utilizado de forma equivocada, como qualquer outro 
procedimento. Esse método nos deixa uma lição para hoje: seu caráter libertador. Ou seja, ele auxilia os cristãos e a comunidade a se descativarem das más ideologias e das leituras simplistas sobre a realidade. Com este olhar crítico, volta-se à Palavra de Deus e à Tradição eclesial, buscando luzes. Ambas as realidades se iluminam. Alarga-se a espiral hermenêutica da fé. O terceiro momento, o do Agir, visa transformar o sentimento e a percepção em gestos concretos de mudança. Com isso, supera-se o limite de um discurso eclesial eivado de boas intenções, mas sem operatividade pastoral. Vale a pena voltar a ler Medellín, com a perspectiva dos novos desafios. Quais opções pastorais devem ser retomadas ou recriadas? O que o momento histórico, diferente de Medellín, exige de nós?

f) As mediações socioanalíticas, utilizadas em Medellín, exigem uma postura prévia. Na sua clássica obra "Libertação da Teologia”, Juan Luis Segundo sustenta que o primeiro passo para alforriar a pastoral e a teologia não consiste na análise da realidade, com instrumentais de diferentes ciências e saberes, mas em sensibilizar-se (SEGUNDO, 1978). Somente quem exercita a atitude de deixar ecoar no coração o sofrimento humano, busca transformá-lo. O primeiro passo não consiste em recorrer à ciência, e sim em exercitar a compaixão. Colocar-se próximo dos seres humanos (e da natureza), onde a vida clama por libertação. A sensibilidade aos Sinais dos Tempos é o pressuposto para a leitura destes sinais. Assim, adquire tanta importância o documento Pobreza na Igreja, de Medellín. No dizer popular: "próximo dos olhos, perto do coração". Ou no axioma da teologia da libertação: o lugar social condiciona o lugar hermenêutico. A Opção pelos pobres soa como fora de moda, quando a Igreja (e as Igrejas) entra na lógica do mercado, do sucesso, da prosperidade individual, da autorreferência. Mas se mostra profética e significativa, diante de um mundo cansado, de uma cultura egoica, enferma e insaciável por consumo. Somente quem se coloca próximo das periferias sociais e existenciais compreende o caráter evangélico da opção pelos pobres. Por isso também, Medellín continua sendo um marco irrenunciável no nosso continente.

g) Vivemos um momento em que muitos movimentos, comunidades e paróquias se enredam em normas litúrgicas, associadas às mais esdrúxulas 
manifestações devocionais, que beiram a insensatez. Proliferam-se os espetáculos! A lista não termina: descida de padre com tirolesa até o altar; uso de aspersor de inseticida para lançar água benta sobre os fiéis; gigantescos ostensórios de ouro reluzente; vestes litúrgicas barrocas, com muita cor e brilho para realçar o sacerdote (e não Jesus); e até o "santíssimo sacramento voador”, teleguiado por um drone. É momento de retomar o documento Liturgia de Medellín, e enriquecê-lo com contribuições contemporâneas. Lá se encontram critérios teológicos e sugestões pastorais em vista de uma liturgia sóbria, equilibrada, encarnada, simultaneamente fiel à realidade local e à catolicidade.

h) Perpassa em Medellín um sentimento e uma convicção: precisamos somar, associar-nos aos outros, para anunciar a Boa Nova do Reino de Deus e contribuir na promoção integral do ser humano e das comunidades do continente. Nota-se uma atitude humilde: "não temos soluções técnicas, nem remédios infalíveis. Queremos sentir os problemas, perceber as exigências, compartilhar as angústias, descobrir os caminhos e colaborar nas soluções” (CELAM, 2010, p. 30). Além disso, a Conferência apela para atuação em conjunto. No âmbito da Igreja católica, promovendo formas originais de colegialidade e articulação de diversas instâncias. No campo religioso, realizando várias atividades com outras igrejas cristãs. Na maioria dos documentos, há referências e sugestões pastorais concernentes ao ecumenismo. Infelizmente, devido à competição selvagem deslanchada pelas "igrejas do mercado" e à tendência católica de introversão, o ecumenismo murchou. É hora de revigorá-lo.

Por fim, no que diz respeito à ação transformadora na sociedade, Medellín apela aos diversos atores sociais e seus organismos. Reconhece que a eles compete realizar as mudanças necessárias. Neste âmbito, os leigos tem uma importante missão atuar como cidadãos. O propósito da Igreja "é estimular os esforços, acelerar as realizações, aprofundar-lhes o conteúdo, penetrar todo o processo de mudanças com os valores evangélicos (CELAM, 2010, p. 29) 
Medellín fez história. Tornou-se um símbolo. Suscitou práticas inovadoras, em fidelidade renovada à Tradição eclesial. A nós compete continuar o caminho aberto pela Conferência. Ressoam, de forma esperada, estas palavras: "Cremos que estamos numa era histórica. Exige clareza para ver, lucidez para diagnosticar e solidariedade para agir" (CELAM, 2010, p. 29).

\section{REFERÊNCIAS}

BEOZZO, O. Prefácio. In: SOUZA,N; SBARTELOTTI, E. (Org.). Medellín. Memória, profetismo e esperança na América Latina. Petrópolis: Vozes, 2018. p.9-18.

CELAM. Conclusões da Conferência de Medellín, 1968: trinta anos depois, Medellín é ainda atual? 3. ed. São Paulo: Paulinas, 2010.

CELAM. Documento de Puebla (1979). Disponível

em:<http://portal.pucminas.br/imagedb/documento/DOC_DSC_NOME_ARQUI201309 06182452.pdf. >. Acesso em: 07 jul. 2018.

CNBB. Catequese renovada. Orientações e conteúdo. Documentos da CNBB. São Paulo: Paulinas, 1983.

DOMEZI, C. A mulher na conferência de Medellín. In: SOUZA, N; SBARTELOTTI, E.

Medellín. Memória, profetismo e esperança na América Latina. Petrópolis: Vozes, 2018. p. 86-97.

FREIRE, P. Conscientização: teoria e prática da libertação. São Paulo: Cortez-Moraes, 1979. Disponível em:

<http://www.dhnet.org.br/direitos/militantes/paulofreire/paulo_freire_conscientizacao. pdf. >. Acesso em: 07 jul. 2018.

GODOY, M. Conferências Gerais do Episcopado latino-americano. In: PASSOS, J.D; SANCHEZ, W.L. (Org.). Dicionário do Concílio Vaticano II. São Paulo: PaulusPaulinas, 2015. p. 205-217.

GODOY, M; AQUINO JÚNIOR, F. (Org.). 50 anos de Medellín. Revisitando os textos, retomando o caminho. São Paulo: Paulinas, 2017.

JOSAPHAT, C. Colegialidade. In: PASSOS, J.D; SANCHEZ, W.L. (Org.). Dicionário do Concílio Vaticano II. São Paulo: Paulus-Paulinas, 2015· p.149-153.

LIBANIO, J. B. Medellín: história e símbolo. Tempo e presença (1988). Disponível em:<https://observatoriodaevangelizacao.wordpress.com/2018/o5/19/Medellín-historiae-simbolo/>. Acesso em: 07 jul. 2018. 
PADIM, C. Educação libertadora proclamada em Medellín. In: Conclusões da

Conferência de Medellín, 1968: trinta anos depois, Medellín é ainda atual? 3 ed. São Paulo: Paulinas, 2010. p. 227-236.

PAPA FRANCISCO. Exortação apostólica Evangelii Gaudium sobre o anúncio do evangelho no mundo actual. Disponível

em:<https://w2.vatican.va/content/francesco/pt/apost_exhortations/documents/papafrancesco_esortazione-ap_20131124_evangelii-gaudium.html>. Acesso em: o7 jul. 2018.

SEGUNDO, J.L. Libertação da Teologia. São Paulo: Loyola, 1978.

SOUZA,N. Notas sobre os antecedentes históricos da Conferência de Medellín. In:

SOUZA,N; SBARTELOTTI, E. (Org.) Medellín. Memória, profetismo e esperança na América Latina. Petrópolis: Vozes, 2018. p. 23-38.

SOUZA,N; SBARTELOTTI, E. Medellín. Memória, profetismo e esperança na América Latina. Petrópolis: Vozes, 2018.

VAZ, H. C. de Lima. Igreja reflexo vs Igreja-fonte. Cadernos Brasileiros, Rio de Janeiro, n. 46, p. 17-22, mar./abr. 1968.

VIER, Frederico (Org.). Compêndio do Vaticano II: constituições, decretos declarações. 13. ed. Petrópolis: Vozes, 1979. 